\title{
THE INFLUENCE OF TECHNOLOGY ON ARTICLES IN TRAVEL WEBSITES
}

\author{
Imas Istiani \\ IAIN Syekh Nurjati Cirebon, Indonesia \\ imasistiani@ymail.com
}

\begin{abstract}
As one of the oldest genres, travel writing genre has evolved in many shapes and formats. Technology plays a great role in creating another subgenre with some differences from the printed formats. The generic features of travel writing on the internet are relatively simple in using words, only putting the key information of the described places and events, and most of the judgments are subjective evaluation. Yet, online articles provide more room for pictures that give benefits to the authors (to express their judgments), the readers (to create the image of the descriptive texts), as well as to the website traffics (for image is another tool to inquire and attract internet users). The technology also heavily influences the usage of further links and the second person pronoun "you."
\end{abstract}

\section{Introduction}

Travel writing has been wellexplored for the genre had already existed since people knew how to write. From the age of pioneering until the age of traveling, this genre varies significantly both in formats and in its features. They could be written in the forms of fictional works, anthropology reports, travelogues, diary entries, personal recommendations, commercial advertisements, sharing tips, and many others. They also could be printed in various mediums, such as novels, poems, magazines, newspaper, letters, brochures, leaflets, etc.

Since the age of internet, travel articles go online as well. However, they have their own distinctive features that separate them from their precedent format since online travel articles are adjusting to the need of customers. Searching for information through the internet means the users want to have quick yet informative readings. By analyzing how travel writings fulfill the needs of modern readers, I expect to find out how technology affects this genre.

In order to meet the expectation, there are two questions that need to be addressed as follow;

1) What are the generic features of online travel writing?

2) What influences does technology affect on the genre?

\section{Literature Review}

\section{Genre Analysis}

From English for Specific Purposes (ESP), Swales defines that genre is "a class of communicative events" where the members share "structure, style, content and intended audience" (1990, p. 58). Swales' definition is used a lot in genre-based 
pedagogy, mostly when it comes to teaching English both to L1 and L2 speakers in high academic level. Meanwhile, Martin and Rose refer genre "to different types of texts that enact various types of social contexts" (2007, p. 8) by situating their analysis in systemic function linguistics (SFL). Their definition of genre largely applies to analyze the context that situated around the text.

In her research project, Schlueter (2012) concludes that "genre may describe a class of texts that share common formal, organizational, and rhetorical characteristics, which are identified by a community and used to accomplish shared goals" (p. 11). She perceives the importance of communal goals to recognize and understand why some works are written in their own ways.

\section{Travel Writing Genre}

As one of the "old" genres, travel writing has evolved without leaving its distinctive remark: giving the audiences strong impressions of targeted places or cultural objects. As one of the means to promote tourism, Chanpetch argues that travel writers are mostly neutral and free from things that can interfere them such as their relations to the place they visit and write about (2011, p. 2). Therefore, their works are reliable and credible in the way like they assume the readers were the friends they know.

Regarding the characteristics, Alacovska (2015) mentions "two dominant textual features or dominants [Jakobson, 1987] characterize the genre of the travel guidebook: the nonfictionality (referential feature) and performativity (didactic feature)" (p. 607). The non-fictionality expects the authors to write the articles objectively and maintain the validity. Meanwhile, the performativity entrusts the readers the 'reliability' of the travel guides.

\section{Travel Writing on the Internet}

It goes without saying that the internet makes it easy for people to explore any places, from local museums in their own cities to huge famous museums in another side of the world. Not only are they able to search the information of places they want to visit, internet users also can choose which information they prefer to retrieve.

Since the birth of World Wide Web (www), plentiful research works have been done considerably, either focusing on the technology itself or on home pages. Travel writing can be found both in official websites, such as tourism, official governments, cultural organizations, and also in commercial websites such as travel agency, news, magazine, even in personal blogs. Surprisingly, there are not many explorations of the topic on the mentioned websites but personal blogs.

After weblogs (as known as blogs) were created in the mid-1990s (Schlueter, 2012, p. 4), numerous research works had already well explored the genre-based analysis of travel articles in blogs. The genre has been ramified into another type of subgenre where the dominant writers are not tied to specific corporates. Since the writers have their own freedom in writing anything and at any time, 'travelers' blogs are often among strangers whose ties and connections have a temporary and transient nature" (Panteli, Yan, and Chamakiotis, 2011. P. 366).

Herring, Scheidt, Bonus, and Sabrina (2004) argues that travel writing in blogs "neither unique nor reproduced entirely" from the printed version of the genres "but rather constitute a hybrid genre that draws 
from multiple sources, including other Internet genres (p. 2). The Internet is believed to affect the online genre greatly.

\section{Methodology}

Samples were taken randomly via Google search. However, there was a tendency to pick some articles. First, the tourism destination was specifically Washington, DC where its perk as being the capital of the United States is the most sought after by people around the world. Second, the articles were chosen from commercial English websites where the writers were likely set aside their personal judgments. Third, the articles were selected based on numerous places or activities instead of single out particular place or event. In total, there were four samples chosen to represent travel articles which were intended to promote the tourism objects in Washington, DC. Since the pages' content on the websites were not only the articles themselves, some irrelevant kinds of stuff were excluded such as unrelated images, fragments of other articles, external advertisements, further related articles, more information links, etc.

By using Laurence Anthony's AntConc, I would able to find what words were most common, seek specific words, measure the hit occurrences, etc. The software was also helpful in retrieving quickly the sentences I wanted to put in the paper and the file I needed to look up.

\section{Result and Discussion The generic features}

Standard features are needed to frame the basic structure of the articles. Table 1 shows us the generic features of all the samples.

Table 1. The Generic Features.

\begin{tabular}{|c|c|c|c|c|c|}
\hline Features & Sample 1 & Sample 2 & Sample 3 & Sample 4 & Notes \\
\hline $\begin{array}{l}\text { Word } \\
\text { numbers }\end{array}$ & 1483 & 590 & 2754 & 2403 & $\begin{array}{l}\text { Mean: } 1807.5 \\
\text { Median: } 1943\end{array}$ \\
\hline Paragraphs & 21 & 19 & 26 & 34 & $\begin{array}{l}\text { Mean: } 25 \\
\text { Median: } 23.5\end{array}$ \\
\hline Pictures & 6 & 9 & 25 & 17 & $\begin{array}{l}\text { Mean: } 14.25 \\
\text { Median: } 13\end{array}$ \\
\hline Text color & $\begin{array}{l}\text { Title: blue } \\
\text { Main text: } \\
\text { black } \\
\text { Heading: } \\
\text { blue }\end{array}$ & $\begin{array}{l}\text { Title: red } \\
\text { Main text: } \\
\text { black }\end{array}$ & $\begin{array}{l}\text { Title: black } \\
\text { Main text: } \\
\text { black } \\
\text { Heading: } \\
\text { black }\end{array}$ & $\begin{array}{l}\text { Title: } \\
\text { black } \\
\text { Main text: } \\
\text { black } \\
\text { Heading: } \\
\text { black }\end{array}$ & \\
\hline $\begin{array}{l}\text { Further } \\
\text { links (freq) }\end{array}$ & $\begin{array}{l}\text { Underlined } \\
\text { black (37) }\end{array}$ & $\begin{array}{l}\text { Underlined } \\
\text { green (14) }\end{array}$ & Blue (51) & $\begin{array}{l}\text { Underlined } \\
\text { blue (43) }\end{array}$ & $\begin{array}{l}\text { Mean: } 36.25 \\
\text { Median: } 40\end{array}$ \\
\hline $\begin{array}{l}\text { Author's } \\
\text { name } \\
\text { Date posted }\end{array}$ & $\begin{array}{l}\text { Under the } \\
\text { title } \\
\text { After the } \\
\text { author }\end{array}$ & $\begin{array}{l}\text { Not } \\
\text { mentioned } \\
\text { Not } \\
\text { mentioned }\end{array}$ & $\begin{array}{l}\text { Under } \\
\text { introduction } \\
\text { Under the } \\
\text { title }\end{array}$ & $\begin{array}{l}\text { Under the } \\
\text { title } \\
\text { Not } \\
\text { mentioned }\end{array}$ & \\
\hline
\end{tabular}

As Table 1 shows us, word numbers are varied greatly of which the shortest is Sample 2 that has only 590 words. Being the longest article, Sample 
4 that has 2754 words is four times longer than Sample 2. However, the length of article does not always correspond with the number of pictures. Even though Sample 4 records to have the highest number of images which is 25 pictures, Sample 1 shows it has the lowest one.

The colors mostly used in the text are black and blue, except for Sample 2 that puts the title in red and the further links in green. The simple choice of color is intended as not to disrupt the stunning pictures that spread out all over the pages. I suspect that the reason Sample 2 is "braver" in color use is because all the 9 pictures are below after the article ends. Another proof is the fact that the caption of the pictures used in Sample 2 is black, not as bold as the title and the further links.

As part of the articles' identity, it is surprising that only Sample 2 does not mention either the author's name or the published date, except that Sample 4 also does not post the date. Unlike other articles from commercial websites, Sample 2 was taken from Destination DC website, an organization that "manage and market Washington, DC as a premier global convention, tourism and special events destination" (http://washington.org/DCinformation/about-destination-dc).

Therefore, the author of Sample 2 could be a team other than a single person.

\section{The titles and the headings}

All the articles' titles are direct, straightforward and answering four questions of how many $(20,100)$, why (free, top), what (outdoor activities, things to do, places to go), and where (Washington, DC). All the titles are corresponding to Chanpetch's Move 1 (2011), which is introducing the articles by using attractive titles ("free" and "top"). There are three steps in Move 1: "stating the writer and photographer's name", "introducing with editor's introductory note", and "stating the title of the article" (p. 31). The first and the last step are found in all samples (except the writer's name in Sample 2). Whereas the second step is not obligatory in this sub-genre.

Move 2, leading in, could be found in the headings which are "presenting the main destination/event the article" (p. 31). Even though all the titles mention specific number as destinations and/or activities, 3 out of 4 articles $(1,3,4)$ do not put number in the headings. Sample 1 and Sample 4 use imperative word in the headings. Interesting to note is, the paragraphs under the headings in both samples mostly show the readers what they can do instead of the description of the places. Meanwhile, Sample 3 uses only the name of the places in the heading, in which the contents of the paragraph tend to tell the backgrounds, histories or description of the places. As for Sample 2 , since the texts are much shorter than the others, this article uses number to jump between one short paragraph to another.

Short informational background

There are several ways to tell readers of key facts or information in the places or activities, either by Move 3 "pointing to the attraction/event, Move 4 "depicting the writer's experience, sensation and thought," or Move 5 "closing-up to the attraction/event" (p. 32). Even so, Move 4 is rarely found since travel articles on the internet are relatively short, too short to put everything within.

Therefore, depending on what types of the places are, the articles only provide the most important information to grab the readers' attention. Too much information can make the articles too 
long to read that can lead to losing attention instead. The length of the articles is short enough to keep the readers' attention yet useful and interesting.

Below is some key information that the articles provide:

- The beautiful trail along the Chesapeake \& Ohio Canal runs from Georgetown to Cumberland, Maryland, for around 180 miles. (Sample 1, Move 3)

- During peak season, there are more than 30 farmers offering items which include fruits and vegetables, meats, cheeses, fish and baked goods. (Sample 2, Move 5)

- Several expansions and restorations over the years have altered the footprint, but the neoclassical façade looks much as it did in James Hoban's original design. (Sample 3, Move 5)

- The 91-acre wilderness preserve serves as a memorial to the nation's 26th president, honoring his contributions to conservation of public lands for forests, national parks, wildlife and bird refuges, and monuments. (Sample 4, Move 5)

By giving the products/places' details and closing-up to the attraction and events, these articles can sell the destinations more convincingly. But still, being concise and straightforward is maintained so the language would not be exaggerating and too flowery.

\section{Persuasive language}

By using APPRAISAL developed by Martin and Rose (2007), we can see how the writers persuade the readers so they are convinced to go and visit the places written in the articles. However, since the writers set aside their personal feelings and judgments, let's focus on the appreciation for they are all over the texts. Here are the examples found in the text:

Table 2. APPRAISAL text

\begin{tabular}{|c|c|c|c|}
\hline Sa. & Sentences & $\begin{array}{l}\text { Types of } \\
\text { adjective }\end{array}$ & $\begin{array}{l}\text { Modified } \\
\text { noun }\end{array}$ \\
\hline $\mathbf{1}$ & $\begin{array}{l}\text { Washington, DC, is one of the most, err, capital- } \\
\text { friendly cities in the world. }\end{array}$ & $\begin{array}{l}\text { Superlative } \\
\text { evaluation }\end{array}$ & $\begin{array}{l}\text { Generic } \\
\text { place }\end{array}$ \\
\hline 1 & $\begin{array}{l}\text { The beautiful trail along the Chesapeake \& Ohio } \\
\text { Canal }\end{array}$ & $\begin{array}{l}\text { Subjective } \\
\text { evaluation }\end{array}$ & $\begin{array}{l}\text { Specific } \\
\text { place }\end{array}$ \\
\hline 1 & $\begin{array}{l}\text { DC's best meditation spot has to be the West Potomac } \\
\text { Park }\end{array}$ & $\begin{array}{l}\text { Superlative } \\
\text { evaluation }\end{array}$ & $\begin{array}{l}\text { Specific } \\
\text { place }\end{array}$ \\
\hline 1 & $\begin{array}{l}\text { the beautiful cherry trees bloom around March or } \\
\text { April }\end{array}$ & $\begin{array}{l}\text { Subjective } \\
\text { evaluation }\end{array}$ & $\begin{array}{l}\text { Specific } \\
\text { object }\end{array}$ \\
\hline 1 & it's especially beautiful at night & $\begin{array}{l}\text { Subjective } \\
\text { evaluation }\end{array}$ & $\begin{array}{l}\text { Generic } \\
\text { time }\end{array}$ \\
\hline $\mathbf{1}$ & $\begin{array}{l}\text { Who needs the Louvre when you've got this } \\
\text { extraordinary treasure trove }\end{array}$ & $\begin{array}{l}\text { Subjective } \\
\text { evaluation }\end{array}$ & $\begin{array}{l}\text { Specific } \\
\text { object }\end{array}$ \\
\hline 1 & $\begin{array}{l}\text { Take yourself on a fascinating self-guided } \\
\text { neighborhood walking tour }\end{array}$ & $\begin{array}{l}\text { Present } \\
\text { participle }\end{array}$ & $\begin{array}{l}\text { Specific } \\
\text { activity }\end{array}$ \\
\hline 1 & $\begin{array}{l}\text { Dumbarton Oaks Park is the coolest place to be at the } \\
\text { height of the humidity. }\end{array}$ & $\begin{array}{l}\text { Superlative } \\
\text { evaluation }\end{array}$ & $\begin{array}{l}\text { Specific } \\
\text { place }\end{array}$ \\
\hline
\end{tabular}




\begin{tabular}{|c|c|c|c|}
\hline 1 & $\begin{array}{l}\text { Witness the most important signatures in US history } \\
\text { at the National Archives }\end{array}$ & $\begin{array}{l}\text { Superlative } \\
\text { evaluation }\end{array}$ & $\begin{array}{l}\text { Specific } \\
\text { object }\end{array}$ \\
\hline 1 & $\begin{array}{l}\text { The greenhouse conservancy and the children's garden } \\
\text { are particularly beautiful spots to stroll through. }\end{array}$ & $\begin{array}{l}\text { Subjective } \\
\text { evaluation }\end{array}$ & $\begin{array}{l}\text { Specific } \\
\text { place }\end{array}$ \\
\hline 1 & jazz is big here & Size & $\begin{array}{l}\text { Specific } \\
\text { object }\end{array}$ \\
\hline 1 & $\begin{array}{l}\text { This beautiful building houses the largest library in } \\
\text { the world }\end{array}$ & $\begin{array}{l}\text { Subjective } \\
\text { evaluation }\end{array}$ & $\begin{array}{l}\text { Specific } \\
\text { place }\end{array}$ \\
\hline 2 & $\begin{array}{l}\text { take in the beautiful colors and see the pillars from } \\
\text { the original U.S. Capitol }\end{array}$ & $\begin{array}{l}\text { Subjective } \\
\text { evaluation }\end{array}$ & $\begin{array}{l}\text { Specific } \\
\text { object }\end{array}$ \\
\hline 2 & take in art and fresh air at the same time & $\begin{array}{l}\text { Subjective } \\
\text { evaluation }\end{array}$ & $\begin{array}{l}\text { Specific } \\
\text { object }\end{array}$ \\
\hline 2 & Discover a hidden treasure & $\begin{array}{l}\text { Past } \\
\text { participle }\end{array}$ & $\begin{array}{l}\text { Specific } \\
\text { object }\end{array}$ \\
\hline 2 & Enjoy a veritable feast & Qualifier & $\begin{array}{l}\text { Specific } \\
\text { object }\end{array}$ \\
\hline 2 & a beautiful 18th-century cobblestone path & $\begin{array}{l}\text { Subjective } \\
\text { evaluation }\end{array}$ & $\begin{array}{l}\text { Specific } \\
\text { place }\end{array}$ \\
\hline 2 & a cooling station for geese & $\begin{array}{l}\text { Present } \\
\text { participle }\end{array}$ & $\begin{array}{l}\text { Specific } \\
\text { place }\end{array}$ \\
\hline 2 & DC's most recognizable monument & $\begin{array}{l}\text { Superlative } \\
\text { evaluation }\end{array}$ & $\begin{array}{l}\text { Specific } \\
\text { object }\end{array}$ \\
\hline 2 & $\begin{array}{l}\text { Take time to pay your respects at the stunning } \\
\text { National World War II Memorial }\end{array}$ & $\begin{array}{l}\text { Present } \\
\text { participle }\end{array}$ & $\begin{array}{l}\text { Specific } \\
\text { place }\end{array}$ \\
\hline 2 & $\begin{array}{l}\text { The C\&O Canal is one of the strongest surviving } \\
\text { achievements of } 19^{\text {th }} \text { century America, }\end{array}$ & $\begin{array}{l}\text { Superlative } \\
\text { evaluation }\end{array}$ & $\begin{array}{l}\text { Specific } \\
\text { place }\end{array}$ \\
\hline 2 & $\begin{array}{l}\text { Claus Oldenburg's monumental typewriter eraser } \\
\text { leaves an indelible impression }\end{array}$ & $\begin{array}{l}\text { Subjective } \\
\text { evaluation }\end{array}$ & $\begin{array}{l}\text { Specific } \\
\text { object }\end{array}$ \\
\hline 2 & Eight hundred acres of gorgeous park & $\begin{array}{l}\text { Subjective } \\
\text { evaluation }\end{array}$ & $\begin{array}{l}\text { Specific } \\
\text { place }\end{array}$ \\
\hline 3 & $\begin{array}{l}\text { DC combines the best of America with a distinct } \\
\text { international flavor. }\end{array}$ & Qualifier & $\begin{array}{l}\text { Specific } \\
\text { object }\end{array}$ \\
\hline 3 & $\begin{array}{l}\text { Home to the First Family, the nation's most famous } \\
\text { address needs no introduction. }\end{array}$ & $\begin{array}{l}\text { Superlative } \\
\text { evaluation }\end{array}$ & $\begin{array}{l}\text { Specific } \\
\text { place }\end{array}$ \\
\hline 3 & $\begin{array}{l}\text { the National Mall is one of the most picturesque and } \\
\text { landmark-filled strolls in the country. }\end{array}$ & $\begin{array}{l}\text { Superlative } \\
\text { evaluation }\end{array}$ & $\begin{array}{l}\text { Specific } \\
\text { place }\end{array}$ \\
\hline 3 & an easy walk or drive from the city & $\begin{array}{l}\text { Subjective } \\
\text { evaluation }\end{array}$ & $\begin{array}{l}\text { Generic } \\
\text { activity }\end{array}$ \\
\hline 3 & $\begin{array}{l}\text { home to two of the largest and most prestigious } \\
\text { libraries in the country }\end{array}$ & $\begin{array}{l}\text { Superlative } \\
\text { size and } \\
\text { evaluation }\end{array}$ & $\begin{array}{l}\text { Specific } \\
\text { place }\end{array}$ \\
\hline 3 & $\begin{array}{l}\text { the John F. Kennedy Center for the Performing Arts is } \\
\text { one of the largest U.S. performing arts facilities }\end{array}$ & $\begin{array}{l}\text { Superlative } \\
\text { evaluation }\end{array}$ & $\begin{array}{l}\text { Specific } \\
\text { place }\end{array}$ \\
\hline 3 & catch a glimpse of the famous Watergate complex, & $\begin{array}{l}\text { Subjective } \\
\text { evaluation }\end{array}$ & $\begin{array}{l}\text { Specific } \\
\text { place }\end{array}$ \\
\hline 3 & A building so big it requires six zip codes & Size & $\begin{array}{l}\text { Specific } \\
\text { place }\end{array}$ \\
\hline
\end{tabular}




\begin{tabular}{|c|c|c|c|}
\hline 3 & $\begin{array}{l}\text { in its astonishingly large confines; at its widest point, } \\
\text { the Pentagon is almost as wide as the Empire State } \\
\text { Building is tall. }\end{array}$ & Size & $\begin{array}{l}\text { Specific } \\
\text { place }\end{array}$ \\
\hline 3 & the highest court in the land & $\begin{array}{l}\text { Subjective } \\
\text { size }\end{array}$ & $\begin{array}{l}\text { Specific } \\
\text { place }\end{array}$ \\
\hline 3 & $\begin{array}{l}\text { For a quiet respite from the many hallowed halls of } \\
\text { D.C. }\end{array}$ & $\begin{array}{l}\text { Subjective } \\
\text { evaluation }\end{array}$ & $\begin{array}{l}\text { Generic } \\
\text { activity }\end{array}$ \\
\hline 3 & $\begin{array}{l}\text { Gravelly Point is the perfect spot for plane spotting at } \\
\text { close range. }\end{array}$ & $\begin{array}{l}\text { Subjective } \\
\text { evaluation }\end{array}$ & $\begin{array}{l}\text { Specific } \\
\text { place }\end{array}$ \\
\hline 3 & $\begin{array}{l}\text { The peaceful, wooded parkland is only a twenty- } \\
\text { minute drive }\end{array}$ & $\begin{array}{l}\text { Subjective } \\
\text { evaluation }\end{array}$ & $\begin{array}{l}\text { Specific } \\
\text { place }\end{array}$ \\
\hline 3 & $\begin{array}{l}\text { some of Washington's most prominent sights can be } \\
\text { found simply by walking down the street. }\end{array}$ & $\begin{array}{l}\text { Superlative } \\
\text { evaluation }\end{array}$ & $\begin{array}{l}\text { Generic } \\
\text { place }\end{array}$ \\
\hline 3 & $\begin{array}{l}\text { the Tidal Basin is one of the most tranquil spots in } \\
\text { the city }\end{array}$ & $\begin{array}{l}\text { Superlative } \\
\text { evaluation }\end{array}$ & $\begin{array}{l}\text { Specific } \\
\text { place }\end{array}$ \\
\hline 3 & as the site of numerous elaborate mansions & Qualifier & $\begin{array}{l}\text { Generic } \\
\text { place }\end{array}$ \\
\hline 3 & $\begin{array}{l}\text { making it a comfortable walk through the northwest } \\
\text { part of the city }\end{array}$ & $\begin{array}{l}\text { Subjective } \\
\text { evaluation }\end{array}$ & $\begin{array}{l}\text { Generic } \\
\text { activity }\end{array}$ \\
\hline 4 & $\begin{array}{l}\text { exploring some of the smaller and more unique } \\
\text { destinations as well }\end{array}$ & $\begin{array}{l}\text { Comparativ } \\
\text { e size and } \\
\text { evaluation }\end{array}$ & $\begin{array}{l}\text { Generic } \\
\text { place }\end{array}$ \\
\hline 4 & you will be sure to have a memorable trip. & $\begin{array}{l}\text { Subjective } \\
\text { evaluation }\end{array}$ & $\begin{array}{l}\text { Generic } \\
\text { activity }\end{array}$ \\
\hline 4 & $\begin{array}{l}\text { The } 19 \text { museums are among the most popular } \\
\text { attractions in Washington DC }\end{array}$ & $\begin{array}{l}\text { Superlative } \\
\text { evaluation }\end{array}$ & $\begin{array}{l}\text { Generic } \\
\text { place }\end{array}$ \\
\hline 4 & $\begin{array}{l}\text { cover a wide range of subjects from art to space } \\
\text { exploration }\end{array}$ & Size & $\begin{array}{l}\text { Generic } \\
\text { object }\end{array}$ \\
\hline 4 & Our national monuments are truly spectacular & $\begin{array}{l}\text { Subjective } \\
\text { evaluation }\end{array}$ & $\begin{array}{l}\text { Generic } \\
\text { object }\end{array}$ \\
\hline 4 & $\begin{array}{l}\text { The memorials are beautiful at night when they are } \\
\text { illuminated. }\end{array}$ & $\begin{array}{l}\text { Subjective } \\
\text { evaluation }\end{array}$ & $\begin{array}{l}\text { Generic } \\
\text { time }\end{array}$ \\
\hline 4 & $\begin{array}{l}\text { Many of them are open } 24 \text { hours and offer great } \\
\text { views of the city. }\end{array}$ & $\begin{array}{l}\text { Subjective } \\
\text { evaluation }\end{array}$ & $\begin{array}{l}\text { Generic } \\
\text { object }\end{array}$ \\
\hline 4 & $\begin{array}{l}\text { The White House, the Capitol and the Supreme Court } \\
\text { are impressive buildings }\end{array}$ & $\begin{array}{l}\text { Subjective } \\
\text { evaluation }\end{array}$ & $\begin{array}{l}\text { Generic } \\
\text { object }\end{array}$ \\
\hline 4 & $\begin{array}{l}\text { Georgetown is a great place to visit during the day or } \\
\text { evening. }\end{array}$ & $\begin{array}{l}\text { Subjective } \\
\text { evaluation }\end{array}$ & $\begin{array}{l}\text { Specific } \\
\text { place }\end{array}$ \\
\hline 4 & There are plenty of interesting things to see and do & $\begin{array}{l}\text { Subjective } \\
\text { evaluation }\end{array}$ & $\begin{array}{l}\text { Generic } \\
\text { activity }\end{array}$ \\
\hline 4 & $\begin{array}{l}\text { The Washington DC region is lucky to have this } \\
\text { wonderful historic park that offers a quick relief } \\
\text { from hectic city life. }\end{array}$ & $\begin{array}{l}\text { Subjective } \\
\text { evaluation }\end{array}$ & $\begin{array}{l}\text { Specific } \\
\text { place }\end{array}$ \\
\hline 4 & $\begin{array}{l}\text { The Kennedy Center Gift Shops offer a great } \\
\text { selection of unique gifts }\end{array}$ & $\begin{array}{l}\text { Subjective } \\
\text { evaluation }\end{array}$ & $\begin{array}{l}\text { Generic } \\
\text { object }\end{array}$ \\
\hline 4 & $\begin{array}{l}\text { Take a picnic and enjoy spectacular views of the } \\
\text { Potomac River at this National Park }\end{array}$ & $\begin{array}{l}\text { Subjective } \\
\text { evaluation }\end{array}$ & $\begin{array}{l}\text { Generic } \\
\text { object }\end{array}$ \\
\hline
\end{tabular}




\begin{tabular}{llll}
\hline 4 & $\begin{array}{l}\text { Holidays are a great time to enjoy the Estate and its } \\
\text { special programming. }\end{array}$ & $\begin{array}{l}\text { Subjective } \\
\text { evaluation }\end{array}$ & $\begin{array}{l}\text { Specific } \\
\text { time }\end{array}$ \\
4 & $\begin{array}{l}\text { Explore the quaint historic town just over } \\
\text { Subjective }\end{array}$ & Specific \\
the Potomac River from Washington, DC. & evaluation & place \\
4 & Alexandria is a fun place to visit & Subjective & Specific \\
& evaluation & place \\
\hline
\end{tabular}

As the list shows, the appreciation is always positive. Withdrawn from AntConc, three positive adjectives are in the top 100 ranks. They are: "great" (16 times), "beautiful" and "best" (10 times). Table 2 also shows that there are 8 types of modified nouns. From those 56 samples, we can conclude the noun types as seen in Table 3.

Table 3. The adjective types of the modified nouns

\begin{tabular}{lllll}
\hline & Place & Time & Object & Activity \\
\hline Generic & 5 & 2 & 6 & 5 \\
Specific & 25 & 1 & 11 & 1 \\
\hline
\end{tabular}

Mostly the texts evaluate the places, both in generic and specific, such as:

- wonderful historic park

- fun place

- impressive buildings

- most tranquil spots

- the quaint historic town

However, interesting to note is that the articles also appreciate times spent traveling to those places, which is another way to say that visitors' quality time will be guaranteed.

\section{- great time}

- beautiful at night

Another form of APPRAISAL that stands out is the use of superlative degree. The use of superlative convinces the readers that these specific destinations would appear as the greatest, without having to refer to any competitor locations. Also, by using "one of the most" phrase, the writers still could convince the readers of the superiority of the destination without the obligation to compare. Therefore, appreciation would appear stronger with the company of superlative forms. Traced back to Chanpetch, appreciation also can fall into Move 5 which depicts the writer's thought but still in an objective way since the adjectives always entail the nouns.

\section{Technology's influence}

Representative and attractive pictures and/or images

Both offline and online version, travel articles would not be complete without pictures. However, online version has much more picture than the offline ones. All articles are heavily equipped with stunning pictures (as shown in Table 1). Except in Sample 1, the rest of the articles provide picture in each paragraph. However, in Sample 1 \& Sample 2, since they come up with the texts first then followed by the pictures, this arrangement seems to separate the pictures and the texts. Therefore, each picture has a longer caption to remind the readers of what and where the picture belongs to. Meanwhile, in Sample 3 \& Sample 4, the pictures are just above or down the 
subtitles. Therefore, Sample 3 does not put any caption below the pictures and Sample 4 only puts the formal name and the picture's credits.

Aside from its function as the real images of the descriptive text, pictures also give the authors rooms for judgments. The more positive the judgment is, the stronger the effect that the readers can feel. Providing pictures show that the authors believe in the potential strength that the pictures can display and convey. Therefore, the better quality the picture has, the more attention the reader will likely to pay.

Another perk of having many pictures in the articles is the ability to invite more readers whose initial query is due to the pictures. Choi claims that "most image retrieval systems include accompanying descriptions of images to support the search process" (2013, p. 1425). Unlike offline travel article of which pictures cannot lead the readers to the texts, technology makes it possible that pictures and texts can work side by side, whichever the internet users inquired first.

\section{Further links}

Further links are one of the distinctive features of online articles that make it unique. From 100 paragraphs (total of all Samples), there are 145 links inside them. It means, we would expect to find one to two link(s) in each paragraph. Here are the examples of further links found in some articles:

- book a tour pass online or take your chances on a same-day tour pass available at the Capitol Visitor Center. (www.visitthecapitol.gov) (Sample 1)

- Check the White House's website for more information. (Sample 3)
- see a Visitor's Guide to Theodore Roosevelt Island. (Sample 4)

Since further links could be elicited without losing the main point of the text, I assume that they belong to paratext. With strong argument, Alacovska (2015) proposes that "the paratexts that solicit audience participation as a function of genrespecific requirements, and institutional legitimation strategies, speak against the widespread claims of digital technologies enabling the co-optation of audience labour into the capitalist valorisation circuit [see Alacovska, 2013; Bruns, 2008])" (p. 616). The links gain benefits either for the readers, the travel website and the referred website once the readers click other links. However, further links have two opposite sides. At one side, readers will find them helpful if there are further links referred in case they need another or more information. On the other side, further links could also be disturbing when readers click it accidentally and they are taken to another page or website.

\section{Engaging the readers}

AntConc counts that there are 51 use of "you" found in all samples meanwhile 0 hits for the use of "I." All the writers throw away their personal experiences or emotions as if those places were only meant to be for the readers if they visited there. The pronoun "you" is heavily situated in the future tense for the readers are most likely people who have never visited Washington, DC and are probably, at the moment, making the decision to go. Therefore, the internet

Besides the futuristic "you," this second person pronoun is also closely related to the probability modal "can" as shown in Figure 1. 
Figure 1

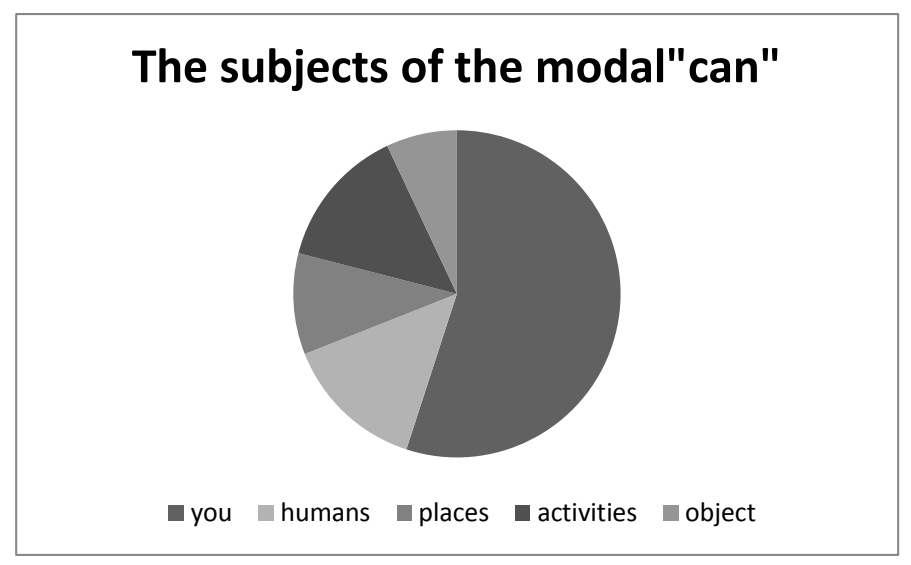

As seen in Fig. 1, more than $50 \%$ the subject for "can" is "you." By entailing "you" with "can," the authors want to impress the readers that they are highly likely able to do some things or feel some emotion if they go visiting Washington, DC. To be said, the combination of "you" and "can" assure the readers of the likelihood experiences as well as attract them to the articles.

For examples:

- where you can hike, horse ride and cycle. The Rock Creek Park Nature Center/Planetarium offers starry experiences (great for kids). (Sample 1)

- you can spend weeks having fun without spending a dime. (Sample 1)

- where you can observe a variety of flora and fauna (Sample 4)

\section{Conclusion}

After analyzing how technology can affect the way travel articles used to be in the print format, the format change is unavoidable. By using Swales' aspects of contemporary life (2004) to assess the context in how genre occurs, the most noticeable aspect is technology. Even though travel writing on the internet is in accordance with the Move established for the print format, the online version tends to be concise, straightforward and filled with pictures. The cycle among the writers, the readers, and the producers results in the increased number of further links as paratext which could be helpful and/or disruptive. Not only the changed format, online travel articles also cast away the judgment and personal emotion of the writers by the heavy usage of "you" and zero "I."

Technology is also filled with commodification for websites, just like offline stores where they "sell" information to the users. Just like offline stores, displaying and selecting their "products" are important in accordance with their initial intention of "building" the websites. This eases the readers to choose and select. As the result, travel articles on the internet are relatively simple but yet, convincing the targeted audiences who are likely people who want to travel with the most of it without spending a dime.

The study needs to be expanded with more samples from other websites. By having larger samples, we can expect more reliable and various findings. There is also a good 
possibility in contrasting and comparing the articles from regular websites and the ones from blogs. Nevertheless, I believe travel writing will always have special places in any media, both online and offline. There is always a room for our feet to explore and discover for earth never ceases to amaze us.

\section{References}

Alacovska, A., (2015). Legitimacy, selfinterpretation, and genre in media industries: a paratextual analysis of travel guidebook publishing. European Journal of Cultural Studies, 18(6), 601619. doi: $10.1177 / 1367549415572318$.

Anthony, L., (2014). AntConc (Version3.4.3)

[ComputerSoftware].

Tokyo, Japan: Waseda University. Available from http://www.laurenceanthony.net/

Chanpetch, J., (2011). A genre-based analysis on rhetorical pattern of travel articles in "Tropical Magazine". Retrieved from Document on Demands Request.

Choi, Y., (2013). Analysis of image search queries on the web: query modification patterns and semantic attributes. Journal of The American Society for Information Science and Technology. 64 (7), 1423-1441. doi: 10.1002/asi.22831

Herring, S. C., Scheidt, L. A., Bonus, S., \& Wright, E. (2004). Briding the gap: a genre analysis of weblogs. Proceedings of the $37^{\text {th }}$ Hawaii International Conference on System Sciences.
http://washington.org/DCinformation/about-destination-dc Retrieved on December 7, 2015.

Martin, J.R., and Rose, D., (2007). Working with discourse: meaning beyond the clause. New York: Bloomsbury.

Panteli, N., Yan, L., \& Chamakiotis, P., (2011). Writing to the unknown: bloggers and the presence of backpackers.

Information Technology \& People. 24(4), 362-377. doi: $10.1108 / 09593841111182241$.

Schlueter, J.L., (2012). Blogging as a matured writing genre: an analysis of formal, organizational, and rhetorical features in blogger and wordpress blogs. UMI Thesis. 1513553.

Swales, J.M. (1990). Genre analysis: English in academic and research settings. New York: Cambridge UP.

Swales, J.M. (2004). Research genres: exploration and application. New York: Cambridge UP. 